\title{
North American Industry Classification System
}

National Cancer Institute

\section{Source}

National Cancer Institute. North American Industry Classification System. NCI

Thesaurus. Code C61432.

The North American Industry Classification System (NAICS) was developed as the standard for use by Federal statistical agencies in classifying business establishments for the collection, analysis, and publication of statistical data related to the business economy of the U.S. It was developed in cooperation with the statistical agencies of Canada and Mexico to establish a 3-country standard that allows for a high level of comparability in business statistics among the three countries. It replaces the Standard Industrial Classification (SIC). 